\title{
Andinopatagonian species of Plagiochila (Plagiochilaceae, Marchantiophyta) Sectio Obcuneatae Carl
}

\author{
Gabriela G. HÄSSEL de MENÉNDEZ \\ Museo Argentino de Ciencias Naturales «Bernardino Rivadavia», Av. A. Gallardo 470, \\ C1405DJR Buenos Aires, Argentina. Wmmail: hassel@macn.gov.ar
}

\begin{abstract}
Sectio Obcuneatae Cari is modified to include Plagiochila subpectinata Besch. \& C. Massal. and $P$. riparia Steph. These taxa, with citation of their type specimens, are described, illustrated, and comments are given on the synonyms, specimens examined, ecology and distribution. Plagiochila fagicola var. $\beta$ subpectinata (Besch. \& C. Massal.) Schiffn., P. hvadesiana Besch. \& C. Massal, P. fagicola Schiffn., P. elegans Gottsche ex Schiffn. n. inval., P.tristis Gottsche ex Schiffn. n. inval, P obcuneata Steph., P. rectangulata Steph., P. arborescens Steph., P flexicaulis var, paucidens Steph. n. inval and $P$ subpectinata fo olivacea Besch. \& C. Massal. n. herb. are considered new synonyms of $P$ subpectinata Besch. \& C. Massal. $P$. fernandeziensis Steph. and $P$ squarrosa Steph. are new synonyms of $P$ riparia Steph.
\end{abstract}

Key words: Liverworts, Plagiochila, taxonomy, Argentina, Chile.

An alphabetic catalogue on the Plagiochila species from Chile and Argentina was presented by Hässel de Menéndez (1983), containing accepted names ( $P$. badia Mitt. was overlooked at that time), other names referred to previous citations and those excluded from the genus. The infrageneric categories by Dugas (1929) and Carl (1931) were not included. As a result of the careful study of new collections from southern South America, a revision of the sections Robustae and Equitantes was published by the author (2004). The present article provides further information on some of the taxa within the Andinopatagonian area.

Carl (1931: 123) emphazised in Sectio Obcuneatae the presence of lateral intercalary branches below the fasciculate male branches, which he also mentioned, appear in female plants. Carl included only Plagiochila obcuneata Steph. in this section (no type specimen was indicated) but he mentioned, that because of the size of the leaf cells, $P$. rectangulata Steph., could also probably be included. $P$, rectangulata is considered by the present author to belong to the synonymy of $P$. subpectinata Besch. \& C. Massal.

In this article the Sectio Obcuneatae is circumscribed to $P$. subpectinata Steph. and $P$. riparia Steph., because of the branching type, the strong lateral intercalary branches and the male fasciculate androecia. This characterization coincides in few words with Carl's description.
Plagiochila subpectinata Besch \& C. Massal., which now includes $P$. obcuneata Steph. as synonym, was not studied by Carl (1931) nor was it cited in the corresponding index.

\section{Sectio Obcuneatae Carl Ann. Bryol. Suppl. 2; 123, 1931.}

Plants with lateral intercalary pinnate branches, and lateral terminal branches of the Frullania type in the proximity of gynoecia and androecia. Strong lateral intercalary branches present, arising from below the pinnate system. Leaves dentate, obcuneate or oval, narrow at the insertion base, distant, orientation squarrose.

Androecia in general fasciculate at apex of shoots, limiting their growth, originating lateral innovations or some of them continuing growth, either as vegetative shoots, or as androecia. Perianth stipitate, cylindric at base and pluristratose.

Type species: Plagiochila subpectinata Besch. \& C. Massal. $(=$ P. obcuneata Steph. $)$.

This section comprises two species:

1) Leaves $1.3-1.6 \mathrm{~mm}$ long, $0.9-1.4 \mathrm{~mm}$ wide; dorsal margin entire but near apex 3-4 short teeth 1 cell long; ventral margin with $6-7$ acute teeth, 3-4 cells long, leaf apex with 1-3 larger curved teeth. Lamina cells $18-28 \mu \mathrm{m}$ in diam. and $21 \mu \mathrm{m}$ thick, cell walls thin with 
small trigones. Ventral lobe of perigonial bracts with 2 short apical teeth. Perianth (when sterile, sessile, cup shaped) $3.0 \mathrm{~mm}$ long, stipitate at cylindric base, above inflated, distally compressed, mouth opening to $1.4 \mathrm{~mm}$ wide, the border dentate with triangular teeth.

Plagiochila subpectinata Besch. \& C. Massal.

2) Leaves $1.3-3.0 \mathrm{~mm}$ long, $1.0-2.7 \mathrm{~mm}$ wide; dorsal margin entire, ventral margin serrate with (23)-26-28 teeth, the uniseriate filament $1-5(-8)$ cells long. Lamina cells $23-38 \mu \mathrm{m}$ in diam. and $26 \mu \mathrm{m}$ thick; cell walls thin except $2-4$ rows of marginal cells with thickened walls. Ventral lobe of perigonial bracts with 5-6 apical teeth. Ferianth $6.0 \mathrm{~mm}$ long, 2.0 $\mathrm{mm}$ wide at ciliate mouth (cilia $1-5$ cells long); at base cylindric, above laterally compressed with dorsal and ventral keels. .Plagiochila riparia Steph.

\section{Plagiochila subpectinata Besch. \& C. Massal., Bull. Mens. Soc. Linn. Paris 1: 628, $1886(1889)$. \\ (Figs. 1-4)}

= Plagiochila fagicola var. B subpectinata (Besch. \& C. Massal.) Schiffn., Forschungsreise \&, M. S. Gazelle 4 (4): 5, 1890 «1889». Typus: Chile, Camden I., passage Brecknock, Hahn 168 (VER ! lectotypus, BM !, FI ! isolectotypi) (Hässel de Menéndez 1983).

= Plagiochila hyadesiana Besch. \& C. Massal. Buh. Mens. Soc. Linn. Paris 1: 628, 1886 (1889). syn. now Typus: Chile, Hoste I., inter Symphyogyna crassifrons, Dr. Hyades 920 (VER! holotypus, designated here, FI! isotypus).

= Plagiochila fagicola Schiffn., Forschungsreise S. M. S. Gazelle 4: 15, pl. 1, figs. 18-19, 1890 «1889» syn. nov. Typus: Chile, Tuesday Bay, Waldsaum am Fagus betuloides, Gazelle Exp. Naumarn 2-2-76 sub var. typica (FH ! holotypus) (Hässel de Menéndez 1983).

= Plagiochila elegans Gottsche ex Schiffn., Forschungsreise S. M. S. Gazelle 4: 5, 1890 «1889» n. inval. syn. nov. Original material: Chile, Fretum Magellanicum, Tuesday Bay, Naumann.

= Plagiochila tristis Gottsche ex Schiffn., Forschungsreise S. M. S. Gazelle 4: 5, 1890 «1889" n. inval. Original material: Chile, Fretum Magellanicum, Tuesday Bay, Naumann.

= Plagiochila obcuneata Steph., Bih. Kongl. Svernska Vetensk.-Akad. Handl. 26 af. III (6): 30, 1.900 syn. nov. Typus: Chile, Patagonia occidentalis, Guaitecas I., Dusén 384 (UPS ! lectotypus, M!, S!, isolectotypi); I. Newton ad Columbine Cove, Dusén 214 (G 20352 !, UPS !, SGO 088700 !); prope Pto.
Varas in Quebrada del Diavolo in terra crescens, Dusén (syntypi) (Hässel de Menéndez 1983).

= Plagiochila rectangulata Steph., Bih. Kongl. Svenska Vetensk.- Akad. Hand1. 26 af. III (6): 31, 1900 syn. nov. Typus: Chile, Patagonia occidentalis, Pto. Bueno in terra, Dusén 109 (M! typus).

= Plagiochila arborescens Steph., Kongl. Svenska. Vetensk. -Akad. Handl. 46 (9): 26, 1911 syn. nov. Typus: Chile, Magallanes, Félix I., Skottsberg 263 (UPS !, G 29840 !, SGO 088743 ! isotypi).

= Plagiochila flexicaulis var. paucidens Steph., Kongl. Svenska Vetensk. -Akad. Handl. 46 (9): 30. $1911 \mathrm{n}$. inval. syn. nov. Original material: Chile, Patagonia occidentalis, Pacheco $\mathrm{I}$, in lacusculo, Halle \& Skotisberg 27-V-1908 (UPS !).

= Plagiochila subpectinata fo. olivacea Besch. \& C. Massal. n. herb. Original material: Chile, Cambden I., Brecknock, Hahn 628 (VER !, FI!).

\section{Illustrations}

Bescherelle et Massalongo (1889) pl. 2 fig. V; Bescherelle et Massalongo (1889) pl. 2 fig. VI, as Plagiochila hyadesiana Besch. \& C. Massal.; Dugas (1929) fig. 39, as Plagiochila hyadesiana Besch. \& C. Massal.; Schiffner (1889) pl. II fig. 13, as Plagiochila fagicola var. B subpectinata (Besch. \& C. Massal.) Schiffn.; Schiffner (1889) pl. I fig. 18-19, typus of Plagiochila fagicola Schiffn.; Stephani (1911) fig. 10 a, typus of Plagiochila arborescens Steph.

\section{Description}

Plants dendroid, $7.0-12-? \mathrm{~cm}$ long. Stem dark brown at base, cylindric, dorsi-ventrally flattened, $244-293 \mu \mathrm{m}$ ( \pm 18 cells) wide, $195-200$ $\mu \mathrm{m}$ thick; with distant leaves. Branches lateral intercalary, pinnate at apex. Strong lateral intercalary innovations from below the pinnate growth limited by gynoecia; these giving rise to a similar pinnate branch system, with or without intermediate leaves. Cortex 3-stratose, cells with brown thickened walls; medulla cells with hyaline thin walls, all 14-19 um in diam.; cuticle $7 \mu \mathrm{m}$ thick. Stolons present in lower parts of the plant. Leaves quite distant, squarrose, obcuneate to oval, increasing in size acropetally along stem and obtaining largest size on branches, but diminishing towards apex, $1.30-1.66 \mathrm{~mm}$ long, (0.48)-0.92-1.48 $\mathrm{mm}$ wide; insertion short oblique with ventral inverted $U$ arch; cnemis oblique; lamina nearly flat, oblique to stem; dorsal border flat, entire, near the apex of leaf 3-4 short, acute teeth 1 cell long directed to the apex; ventral border rounded when well developed with 6-7 distant acute triangular $3-4$ cell long teeth with 


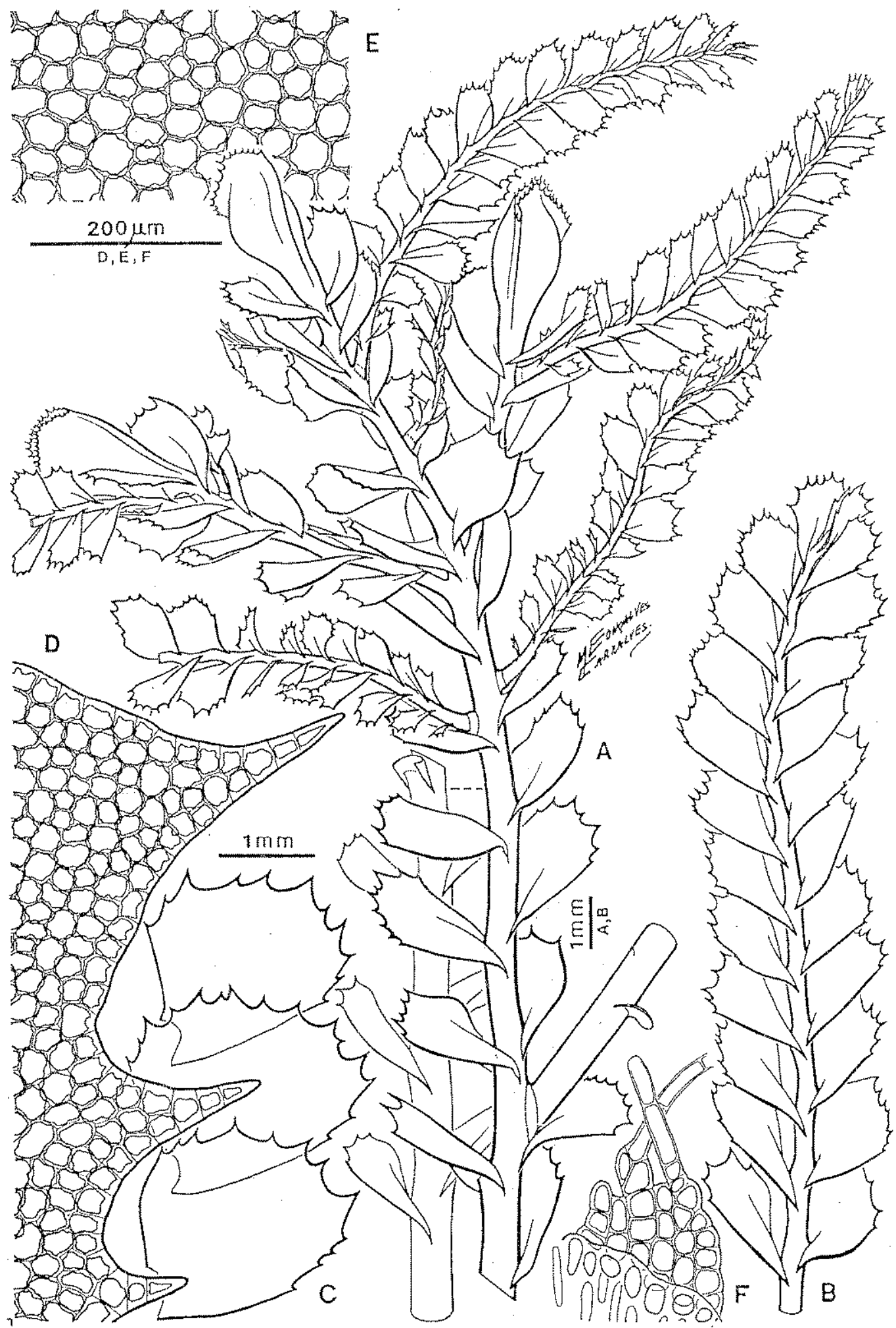

Fig. 1. Plagiochila subpectinata Besch. \& C. Massal.- A Dorsal view of part of female plant.-B Dorsal view of branch.- C Leaves.- D Detail of apex of leaf.- $E$ Leaf cells.- F Amphigastrium. A-F from Virtudes I. Eskuche 138-E23 (CTESN). 
thickened cell walls, and at the leaf apex 1-3 larger curved teeth. In small leaves the teeth number is reduced and no marginal lateral teeth are present. Lamina cells $18-28 \mu \mathrm{m}$ in diam., 21 um thick, with slightly thickened walls and small trigones and sometimes small intermediate thickenings; basal cells enlarged; the border thickened in marginal cells. Oil bodies whitish greyish, ovoid to botuliform 8-12 $\mu \mathrm{m}$ long and 3 . $5 \mu \mathrm{m}$ in diam. 4-7 per cell. Dorsal merophyte of stem free of leaves equals $2-3$ cells; ventral merophyte free of leaves is $8-10$ cells wide. Amphigastria small bifid. Dioicous. In male plants 2 or 3 androecia on lateral terminal branches of the Frullania type, at apex of stem or on lateral intercalary branches, slender, lax, fusiform, $0.55 \% 0.74 \mathrm{~mm}$ wide, with $7-8$ pairs of distant perigonial bracts; some androecia successive by alternating with sets of normal vegetative leaves or continuing only like a narrow vegetative branch; underneath additional androecia present of lateral intercalary origin, as well as on new lateral intercalary branches below this system. Bracts to $0.49 \mathrm{~mm}$ long, at apex with 2 short teeth; dorsal ventricose lobe $0.24-0.29 \mathrm{~mm}$ long; 1 antheridium per bract. Female plants with gynoecia at apex of stem and branches with subfloral innovations. Bracts similar to leaves, to $2.2 \mathrm{~mm}$ long and $1.8 \mathrm{~mm}$ wide, distant from perianth. Perianth $3 \mathrm{~mm}$ long, sessile, inflated, frequently with opened mouth when sterile; when sporophyte is developed the perianth is stipitate, $3.3 \mathrm{~mm}$ long, cylindric at base (here multistratose; all cells with very thickened walls), the bilabiate dentate mouth 1.4 $\mathrm{mm}$ wide appears closed but is inflated below; teeth triangular, similar to leaf teeth, the central ones longer than those of the sides. Seta short, exceeding the perianth, $146 \mu \mathrm{m}$ (6-9 cells) in diam. with $18-35$ peripheral cells. Capsule red brown, $0.6 \mathrm{~mm}$ long, 4 - stratose; outer cells with thin walls, $58-70 \mu \mathrm{m}$ long, $35-37 \mu \mathrm{m}$ wide and 23 $28 \mu \mathrm{m}$ thick; inner cells sinuose, $7 \mu \mathrm{m}$ thick with radial and semiannular red brown thickenings. Spores brown, baculate, $14 \mu \mathrm{m}$ in diam. Elaters brown, torn, with 2 helicoidal thickenings, \pm 94 $\mu \mathrm{m}$ long, $7 \mu \mathrm{m}$ in diam.

\section{Discussion on morphology}

The main characters used for the arrangement of the synonymy are the presence of Frullania type branches (a condition which is quite unique in the southernmost species of the genus Plagiochila in southern South America) in addition to the lateral intercalary branches of Plagiochila type, and the fascicles of long male branches at the end of shoots. The leaves are variable, from the simplest form illustrated by Bescherelle \& Massalongo (1889 b), referred to $P$. subpectinata and $P$. hyadesiana, to those more dentate, which are illustrated by Schiffner (1889) in reference to Plagiochila fagicola. There are also differences between sterile perianths, which are short and globose, and those which have developed sporophytes, which look stipitate at their base, while the bilabiate mouth, in lateral view, is expanded; fan shaped and dentate.

\section{Discussion on synonyms and their citations}

Plagiochila subpectinata Besch. \& C. Massal. was also reported by Herzog et al. (1940:6) from Chile, Cerro Tesoro and by Engel (1976:135) from Argentina, Tierra del Fuego, Lapataia. These reports have not been confirmed.

Reports by Stephani (1905:329) of Plagiochila hyadesiana Besch. \& C. Massal. from Chile, Desolación I., (1911:32) from Pto. Chacabuco and Seno Skyring; by Dugas (1929:70) from Cap Horn; by Herzog (1942:704) from Juan Fernández I. and Tierra del Fuego, (1960:186) from Chile, Río Futa; by S. Arnell (1957:6) from Juan Fernández Is., have not been confirmed.

Geissler and Bischler (1989:159) considered Plagiochila fagicola Schiffn. to be a nom. inval. because of Art. 67.1 of the ICBN (= Plagiochila subpectinata Besch. \& C. Massal. 1886). Schiffner (1889:5) indicated, along with the description and locality, -Fretum Magellanicum, Tuesday Bay, 2. 76 with $P$. patagonica-, two varieties [ "alfa typica" and "beta var. subpectinata"], and $P$. tristis Gottsche Ic. Hep. Ined. and P. elegans Gottsche Msc., and mentioned "P. subpectinata Besch. \& C. Massal. ist trotz ihres anderen Aussehens sicher nur eine Form von $P$ fagicola ". Hässel de Menéndez (1983: 101, 120) maintained, at that time, that these were separate species. Engel (1990:147) mentioned the presence of $P$. fagicola, based on an indirect reference, from the Maivinas Is. due to Inoue.

The name Plagiochila tristis was used on three occasions. First by Schiffner (1889:5) for southern South America, as a n. inval. derived from Gottsche Ic. Hep. Ined, without indication of locality. Later, Stephani (1900:33) cited material from Aysen (at UPS, S) under this same name but belonging to $P$. obovata Steph. and finally (1902:240) he described $P$. tristis Steph. from Mexico. However, this plant is not present in the area, as stated by Hässel de Menéndez (1983:122).

Other citations of Plagiochila obcuneata Steph. (now a synonym of Plagiochila subpectinata Besch. \& C. Massal.) are by Stephani (1906:308) from 


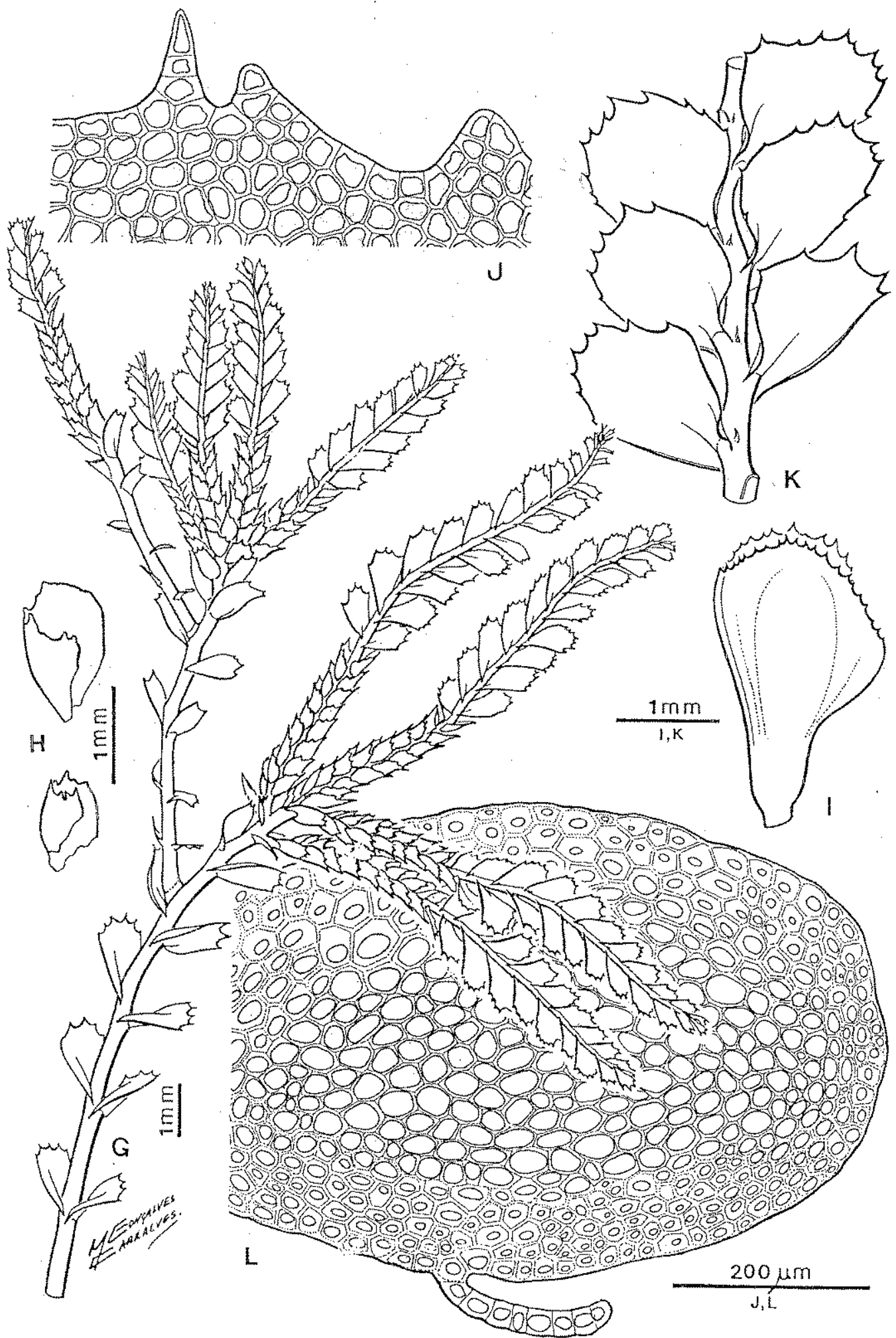

Fig. 2. Plagiochila subpectinata Besch. \& C. Massal.- G Dorsal view of part of male plant.- H Perigonial bracts.- I Perianth.- J Detail of perianth mouth.-K Ventral view of branch.- L Tranverse section of stem. G-L from Virtudes I. Eskuche 138-E23 (CTESN). 


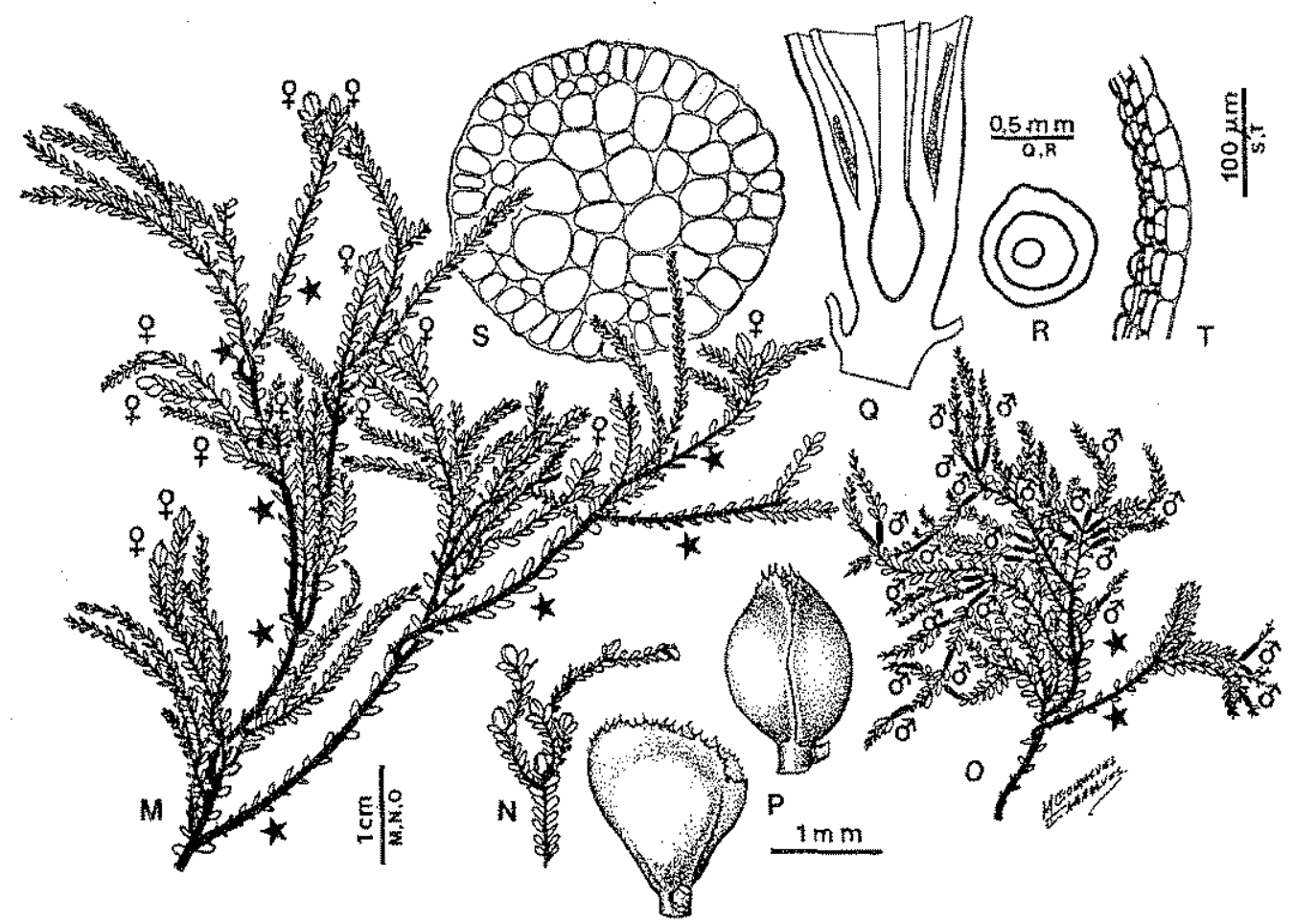

Fig. 3. Plagiochila subpectinata Besch. \& C. Massal.- M Half schematic habitus of female plant, $\star$ represent strong lateral intecalary branches below pinnate branch system. $\mathrm{N}$ representing female plant without sporophytes.- $\mathrm{O}$ Half schematic habitus of male plant, $\star$ representing strong lateral intercalary branches.- $P$ Perianths containing unfertilized archegonia. $Q$ Longitudinal section through perianth with sporophyte., $\mathrm{R}$ Transverse section through base of perianth with sporophyte.S Section through seta.- T Section through capsule wall. M-N from Virtudes I., G. H. M. TBPA-B 1909; O from Ancón Sin Salida, G. H. M. TBPA-B 634; P from Isla de los Estados G. H. M. 4041; QT from Piazzi I. G. H. M. TBPA-B 1091.

Chile Australis and Occidentalis, (1905:324) from Desolación I., by Stephani (1911:32) and Kühnemann (1936:95, 1949:348) from Argentina, Malvinas Is.; by Dusén (1903:7) from west Patagonia, by Massalongo (1906:9) from Chile, Poyo-huapi; by Carl (1931:124) from west Patagonia, by Buch (1934:2) from Tierra del Fuego; by Inoue (1984:85, pl. 5, fig. 5) from Osorno and by Barrera (1991:7) from Newton 1. These citations are all not confirmed.

Except the type of Plagiochila rectangulata Steph. (now a synonym of Plagiochila subpectinata Besch. \& C. Massal.), other specimens reported under this name, have not been analysed, i. e. by Stephani (1901) from Cape Froward, (1904:483) from Patagonia Occidentalis, (1905:29) from Desolación I., (1911:34) from Félix 1., by Carl (1931:135) from Patagonia, by Herzog (1942:705) from Juan Fernández Is., (1957:209) from Argentina, Lago
Moreno, (1960:185) from Chile, Co. Lungoico, by S. Arnell (1957:6) from Juan Fernández Is. Engel (1978:211) mentioned that he had not found the species on the Brunswick Peninsula.

The identity of the specimens cited by Engel (1978:205) and Barrera (1991:6) as Plagiochila arborescens Steph. (now a synonym of Plagiochila subpectinata Besch. \& C. Massal.), has not been confirmed.

Plagiochila flexicaulis var. paucidens Steph. n. inval. was also applied by Reimers (1926:33) to specimens from Chile, Panguipulli; by Herzog (1938:10) to specimens from Valdivia and (1960:186) from Chile. No further information exists about these specimens.

\section{Previous confirmed citations}

CHILE; Aysen by Stephani $(1900 ; 1911)$ as Plagiochila obcuneata Steph.; Guaitecas Is., Pto. Bueno; Piazzi I., Rennel I.,Vidal Gormaz I., Vir- 


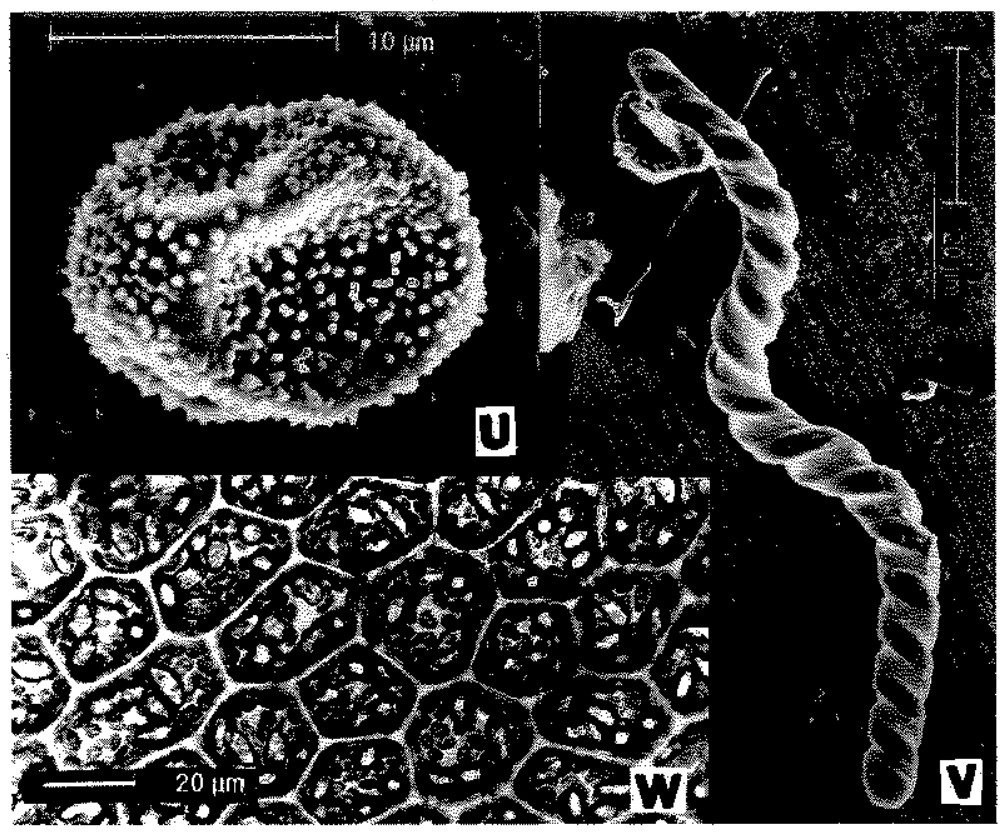

Fig. 4. Plagiochila subpectinata Besch. \& C. Massal.- U Spore.- V Elater- W Detail of leaf cells. U-V from Piazzi I. G. H. M. TBPA-B 1091; W from Isla de los Estados G. H. M. 3133a.

tudes I., Felix I., Pto. Toro, Ancón Sin Salida, Newton I., Pens. Brunswick by Hässel de Menéndez y Solari (1985) as Plagiochila fagicola; Pacheco I., Hoste I. by Hässel de Menéndez (1983) as Plagiochila hyadesiana Besch. \& C. Massal.; Fretum Magellanicum by Stephani (1917) as Plagiochila arborescens Steph.; Fretum Magellanicum by Stephani (1904) as Plagiochila fagicola Schiffn.; Pto. Chacabuco, and Chiloé by Stephani (1911) as Plagiochila obcuneata Steph.; Straits of Magellan by Hässel de Menéndez (1983) as Plagiochila fagicola Schiffn,; Fuegia by Stephani (1904); Brecknock by Hässel de Menéndez (1983); Hoste I., by Bescherelle et Massalongo (1889) as Plagiochila hyadesiana Besch. \& C. Massal.; Fretum Magellanicum by Stephani (1903) as Plagiochila hyadesiana Besch. \& C. Massal. ARGENTINA: Tierra del Fuego, Hässel de Menéndez y Solari (1985).

\section{Specimens examined}

CHILE; Valdivia, La Unión, Guallería, 600-800 $\mathrm{m}$, Sparre 3717 p. p. ( $($ ) ) (US); id. (S as P. chiloensis Steph.); id. Sierra Pelada, camino de Unión a Hueicolla, Chivería, G. H.M.* 2333 ( $q$ ), 2345; id. Cerro Mirador, turbera, G. H. M. 2259 (0 ); Los Ulmos, paredón en antigua carretera, G. H. M. 10776 ( (); Pto. Chacabuco, ad truncos, Halle 285
(S as $P$ obcuneata Steph.); camino de Pto. Chacabuco a Pto. Aysen, Lago Riesco, Drehwald 576 (DREHWALD); Chiloé, "tepual", G. H. M. $11574\left(0^{7}\right)$; id. Chilcón, G. H. M. $11469\left(0^{7}\right)$; I. Refugio, Villagrán $112\left(0^{\circ}\right)$ (VILLAGRAN); carretera entre Coihaique y Puyuhuapi, km 147 pasando Amengual $330 \mathrm{~m}$, G. H. M. \& M. Rubies 12561 ( $0^{7}$ o); Pto. Yungai, cascada, G. H. M. \& M. Rubies 12026 ( $0^{7} \%$ ); Rennel I., Eskuche 61-35 (ㅇ) (CTESN); I. Rennel, G. H. M. TBPA-B 1266b; id. $1326 \mathrm{a}\left(0^{*}\right.$ ㅇ $)$; id. $1355 \mathrm{c}\left(0^{*}\right)$; id. $1539\left(0^{*}\right.$ 우); id. 1604 $\left(\sigma^{\top} Q\right)$; id. 1669b (Q); id. 1842a $\left(\sigma^{\top} Q\right)$; Virtudes I., Pto. Virtudes, Eskuche 138-E22 ( $0^{7}$ \% , c. caps) (CTESN); Virtudes, G. H. M. TBPA-B $1908 b\left(0^{*}\right.$ \%); id. 1909 (\%, c. caps); I. Piazzi, Caleta Ocasión, G. H. M. TBPA-B 1091 ( $\%$, c. caps.); id. 1096 (o' $q$ ); id. $1196 \mathrm{c}$ ( \&); I. Diego de Almagro, G. H. M. TBPAB $1881\left(0^{*}\right)$; Ancón Sin Salida, Seno Unión, G. H. M. TBPA-B 634 (0); id. Eskuche CH 9-22 () (CTESN); Seno Ultima Esperanza, Pto. Bellavista, Cerro Morro, Schiavone TBPA-B 2212 (o); id. Pto Toro, Cerro Balmaceda, Schiavone TBPA-B 2660. I. Desolación, Pto. Angosto, Dusén 162 ( $\%$ ) (S, UPS, BA as P. obcuneata Steph.); id. Dusén 219 (FI as $P$. hyadesiana Besch. \& C. Massal.). ARGENTINA: Tierra del Fuego, Isla de los Estados (Staten I.). Bahía Flinders, G. H. M. 4629; Bahía Hoppner, G. H. M. 4698 (\%); id. 4706 (o , c. caps.); id. 4661 (o'); 
id. 4663; Basil Hall, G. H. M. 4042a; id. 4041 (ㅇ); Pto. Cook. Cascada Arroyo Fernández G. H. M. $3133 a$ (오, c. caps).

$*$ G. H. M. at BA.

\section{Ecology and distribution}

Plagiochila subpectinata Besch. \& C. Massal. is known to be present in Chile, on the continent from Valdivia to the Seno Unión, and on Tierra del Fuego, but also in the Channel Islands, as far as Desolación I. and Hoste I., where it is found on the ground of the Nothofagus betuloides and Pilgerodendron uviferum forest. In Argentina, it was only found on the Isla de los Estados (Staten I.) by Tierra del Fuego.

Plagiochila riparia Steph., Kungl. Svenska. Vetensk. -Akad. Handl. 46 (9): 34, fig. 11 e, 1911.

(Figs. 5-6)

Typus: Chile, Juan Fernández Is., Masafuera, Skottsberg 183, 1908 (G 20873 ! holotypus, here designated, S! isotypus).

$=$ Plagiochila (Jungermannia) dichotoma forma (prior) Nees \& Mont., Ann. Sc. Nat. ser. 2 (5): 53, 1836. (syn. art. 24 ICBN 2000).

$=$ Plagiochila trapezoidea var. a rigescens Gottsche, Lindenb. \& Nees, Syn. Hep.: 50, 1844. (syn. art. 11.2 ICBN 2000). Typus: Chile, Bertero 1563 , hb. Hochstetter (GTR! holotypus, here designated).

= Plagiochila fernandeziensis Steph., Kungl. Svenska. Vetensk. -Akad. Handl. 46 (9): 30. 1911. syn. nov. Typus: Chile, Juan Fernández Is., schattiger Wald am Yunque (typus).

$=$ Plagiochila squarrosa Steph. Spec. Hep. 6: 215, 1921 (non Steph 1900 n. nud.) n. illeg., syn. nov. Typus: Chile, Juan Fernández Is., Masatierra ad Montem Yunque, Skottsberg 24-VIII-1908 (UPS!, G 20880 ! isotypi).

\section{Mllustrations}

Stephani (1911) fig. 11 e, as Plagiochila riparia Steph., Stephani (1911) fig. $11 \mathrm{f}$, as Plagiochila fernandeziensis Steph.

\section{Description}

Plants pale green to yellowish when dry, 7.0$11.0 \mathrm{~cm}$ long, 4.0-6.0 $\mathrm{mm}$ wide between leaf tips of opposite sides, with creeping system composed of naked brown stolons; shoots with pinnate lateral intercalary branches, and others from below originating strong innovating lateral intercalary branches; besides some arise without leaves and are directed towards the substrate.
Stem not straight, rather in a zigzag line, cylindric dorsi-ventrally flattened, 388-436 $\mu \mathrm{m}$ (22-24 cells) wide, $290-340 \mu \mathrm{m}$ thick; cortex 4stratose, outer 2 strata darker brown, the cortical cells $12-14(-18) \mu \mathrm{m}$ in diam. with thickened walls and cuticle; medulla cells $14-18 \mu \mathrm{m}$ in diam. with hyaline walls. Leaves obovate, brittle, $1.3-3.0 \mathrm{~mm}$ long, 1.0-2.7 $\mathrm{mm}$ wide, distant, insertion short oblique and short decurrent; cnemis short oblique and lamina nearly plane giving to the leaves a squarrose appearance in combination with the zigzag branch; dorsal margin entire, scarcely recurved, at rounded apex of leaves and ventral serrate margin about (23-26)-28 teeth, all directed towards tips; teeth at their base $2-4$ cells wide, then uniseriate filament 1-5 (-8) cells long, the uppermost cell is acute; the cells 11-18 $\mu \mathrm{m}$ long, the walls thickened. Lamina cells isodiametric, $23-35 \mu \mathrm{m}$ in diam. and $26 \mu \mathrm{m}$ thick, with small trigones; a small area close to the insertion with elongated cells to $66 \mu \mathrm{m}$ long and $42 \mu \mathrm{m}$ wide with longitudinal walls thickened; the marginal cells in about $2-4$ rows with uniformly thickened cell walls; these thickenings also extending to the teeth; cuticle 4-5 $\mu \mathrm{m}$ thick. Oil bodies 8-18 per cell, spherical, 2-5 $\mu \mathrm{m}$ in diam. Amphigastria reduced. Androecia terminal at apex of shoots, in groups of (2)-3, formed by 1 . terminal androecium and others equivalent to lateral terminal branches, but capable of continuing growth as a vegetative branch with a further intercalary isolated androecium or a terminal group of androecia. Androecia cylindric, 1.5 $\mathrm{mm}$ wide, lax, flexuose, with (4)-6-9 distant dorsally saccate bracts, nearly all of the same size; the basal bract due to its lateral terminal origin is small; the bracts in general are $0.4 \mathrm{~mm}$ long; dorsal lobe ventricose not touching dorsally opposite bract, $0.24 \mathrm{~mm}$ long, the margin entire to repand, stiff and not recurved; ventral lobe stiff, entire except the 5-6 short apical teeth. Gynoecia at apex of shoots or branches with subfloral innovations. Bracts similar to the leaves, but slightly larger; lamina cells $17-23 \mu \mathrm{m}$ in diam., trigones enlarged, nearly confluent; marginal fringe of cells with thickened walls \pm 10 cells wide; area of large cells at base of bracts also larger. Perianth stipitate, $6.0 \mathrm{~mm}$ long and $2.0 \mathrm{~mm}$ wide, at its base cylindric $7-10$ cells thick, above cylindric flattened 2 cells thick, with dorsal and ventral keels; these with some low projections; at mouth perianth one cell thick, the mouth ciliate, teeth with uniseriate filament 1-5 cells long, with thickened cell walls. Seta 7-8 cells in diam, \pm 20 peripheral cells. Sporophyte unknown. Asexual reproduction not present. 


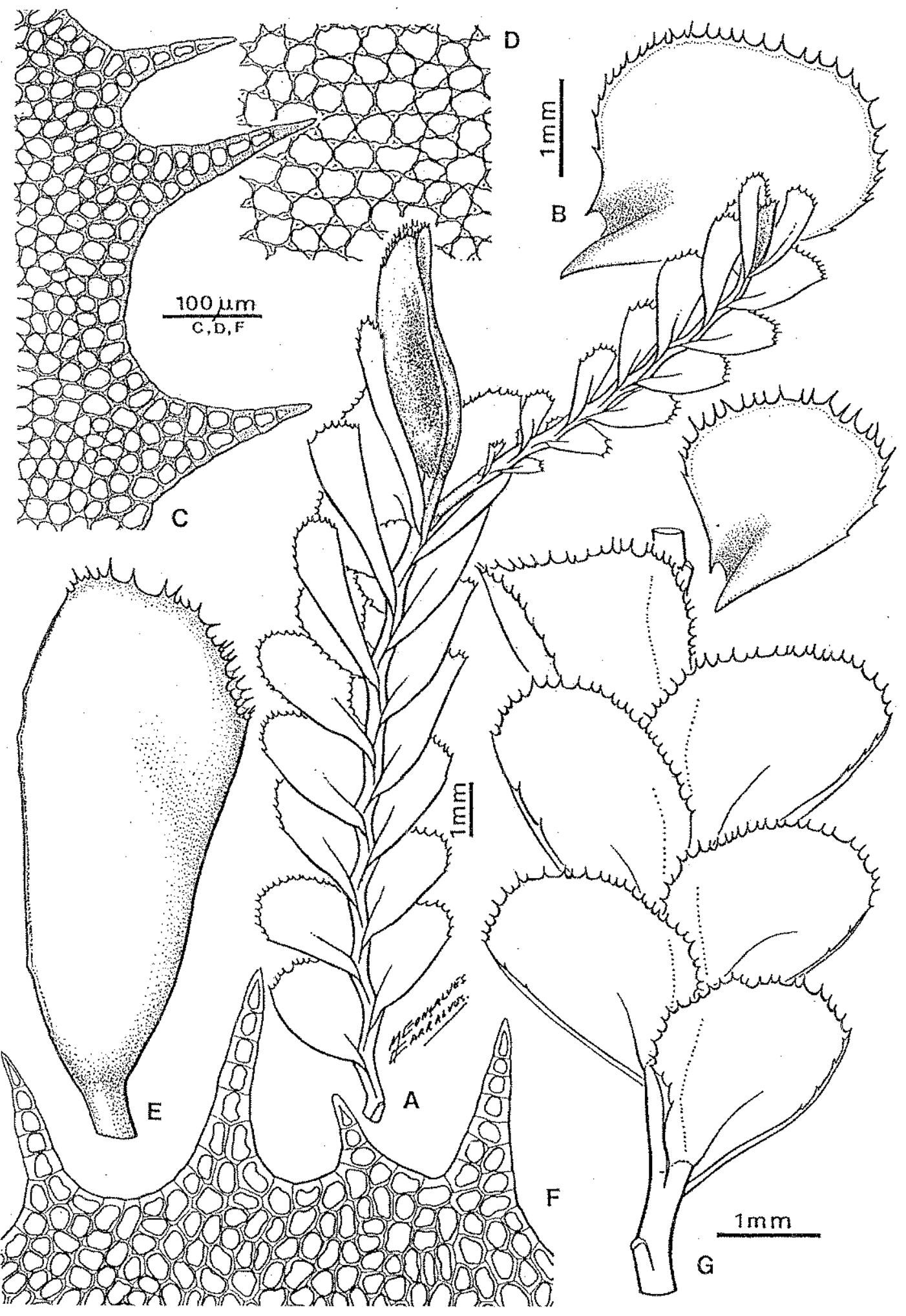

Fig. 5. Plagiochila riparia Steph. - A Dorsal view of part of female plant.- B Leaves. - C Detail of apical portion of leaf.- D Leaf cells.- E Perianth. - F Detail of perianth mouth.- G Ventral view of branch. A-G from Juan Fernández Is., Masafuera, Hatcher \& Engel 555 (MSC). 


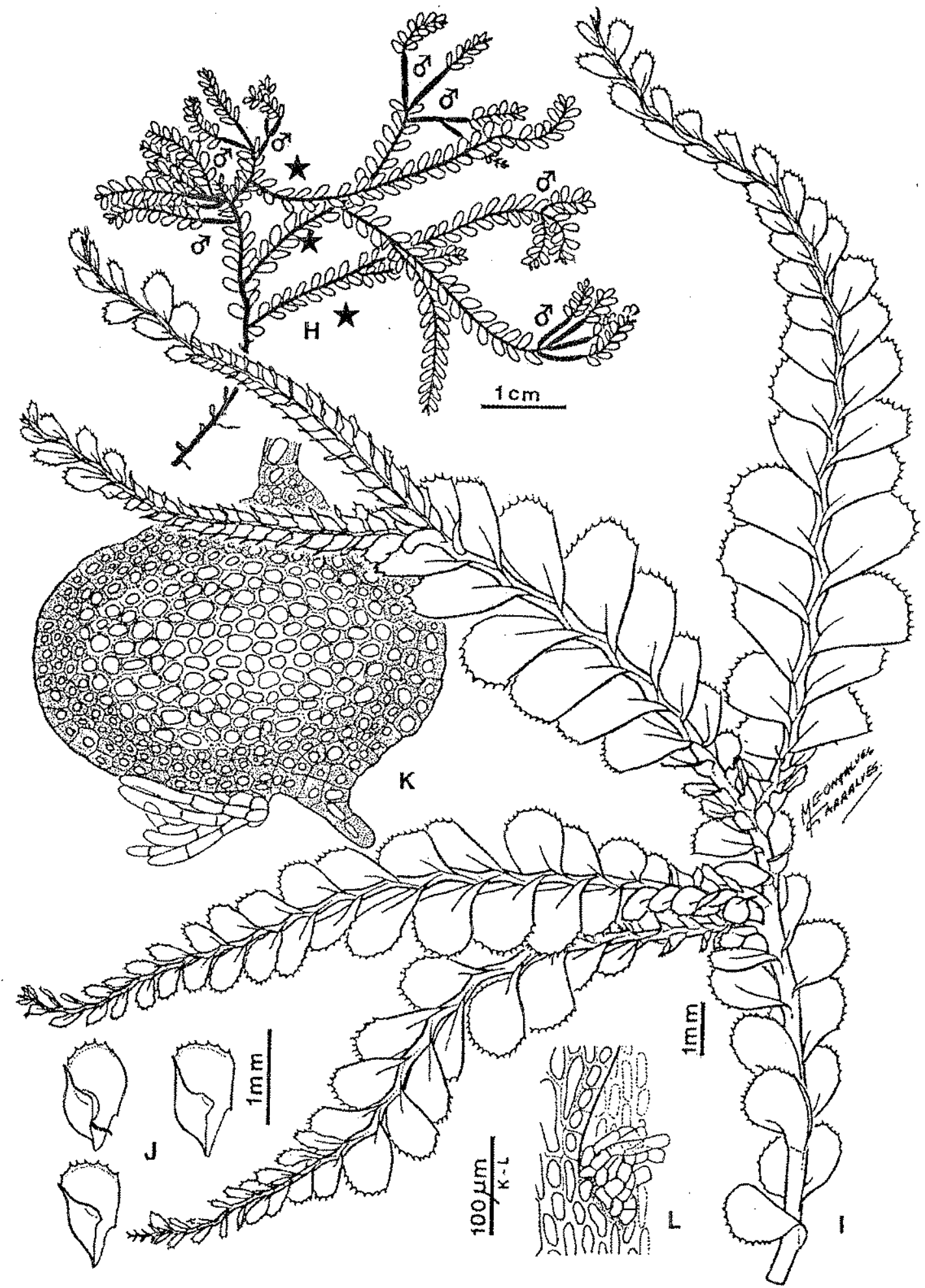

Fig. 6. Plagiochila riparia Steph.- H Half schematic habitus of male plant, $\star$ stronglateral intercalary branches.- I Dorsal view of part of male plant.- J Perigonial bracts.- $K$ Transverse section of stem. L Amphigastrium. H.J from Juan Fernández Is., Masafuera, Hatcher \& Engel 443 (MSC); K-L id. Hatcher \& Engel 555 (MSC). 


\section{Previous confirmed citations}

Chile, Juan Fernández Is., by Hässel de Menéndez (1983: 121) as P. squarrosa Steph.

\section{Discussion}

The first name used to designate this taxon, Plagiochila (Jungermannia) dichotoma forma (prior) Nees \& Mont., cannot be used as a basionym due to the Rules of the ICBN 2000 (art. 23.6). The second name, $P$. trapezoidea var. rigescens, based on the same type specimen, cannot be used either because "var. rigescens" has no priority, as it is outside the rank (art. 11.2).

The type specimen of Plagiochila fernandeziensis Steph., has not been located, as stated by Hässel de Menéndez (1983:102). Herzog (1942:711) considered this name a synonym of Plagiochila squarrosa Steph. Some of these specimens have now been analysed. See specimens examined.

\section{Specimens examined}

CHILE: JUAN FERNANDEZ ISLANDS: Masafuera, trail to Inocentes, Hatcher \& Engel $555\left(0^{7}\right.$ ) (MSC as Plagiochila squarrosa Steph.); id. Camp Correspondencia, Hatcher \& Engel $452\left(\sigma^{7}\right)$ (MSC as $P$. squarrosa); id. Cordón del Barril, C. \& I. Skottsberg 64 (O) (UPS); id. among boulders on steep shaded slope, Hatcher \& Engel $443\left(\sigma^{\circ}\right)$ (MSC as Plagiochila hyadesiana). Masatierra: Piedra Agujereada, C. \& I. Skottsberg 418 (O) (JE as $P$ squarrosa); id. ridge below Piedra Agujereada and Piedra Laura, C. \& I. Skottsberg 48 (\%) (S), id. 61 (o') (S), id. 49 (O) (JE, S); id. Cordón Centinela, C. \& I. Skottsberg 80 b (O) (S); id. 67 ( $\left.\mathrm{O}^{*}\right)$ (UPS as P. squarrosa); id. mountain ridge $S$ of Pangal, $\mathrm{E}$ of Yunque, C. \& I. Skottsberg, St. 29 (UPS as P. squarrosa); id. Salsipuedes, Dicksonia forest (UPS as $P$ squarrosa); id. C. \& I. Skottsberg 58 (ㅇ) (S); Valle Colonial, wood below Portezuelo de Villagra, C. \& I. Skottsberg H16; id. G. Looser 85B (UPS as P. squarrosa); id. Hatcher \& Engel 702 (MSC); id. Slope above Plazoleta del Yunque, C. \& I. Skottsberg ( $\sigma^{*}$ ) (UPS as P squarrosa); Valle Anson, C. \& I. Skottsberg $212\left(0^{*}\right)$ (UPS as P. squarrosa).

\section{Ecology and distribution}

Plagiochila riparia Steph. is known from Chile, Juan Fernández Is., both the Masafuera and Masatierra islands. It was found dwelling from 400 to $3800 \mathrm{ft}$. on the ground among dense shrubbery, also by a trail among boulders on a steep shaded slope, and on the ground in a Dichsonia forest, as well as on the trunk of Blechnum cycadiifolium.

\section{ACKNOWLEDGEMENTS}

I. am very grateful to the Curators of the following herbaria $\mathrm{BM}, \mathrm{FI}, \mathrm{FH}, \mathrm{G}, \mathrm{JE}, \mathrm{M}, \mathrm{MSC}$, S, STR, UPS, VER, for the loan of specimens. I express my thanks to Prof. Dr. David Moore, Dr. Stanley W. Greene to and Dr. Edmundo Pisano V.t , for their invitation to participate in the Transecta Botánica de la Patagonia Austral, which allowed me to obtain many specimens related to this study. I thank Mrs. Matilde Gonçalvez-Carralves for preparing the line drawings, to Mrs. Marta Rubies for her assistance with the literature, the typography of the manuscript and arrangement of the illustrations. The help of Fabián Tricárico and Angel Fusaro of the Servicio de Microscopía Electrónica de Barrido of the MACN is also acknowledged. Financial support was received from the CONICET of Argentina.

\section{BIBLIOGRAPHY}

Arnell, S. 1957. Hepatic collected during Dr. and Mrs. C. Skottsberg's second expedition to the Juan Fernández lslands, Dec. 1954-March 1955. Arh. Bot. II, 4: 1.21 .

Barrera, E. 1991. Ejemplares tipo de Hepáticas conservadas en el Museo Nacional de Historia Natural (Santiago - Chile). Noticiario Mensuat, Museo Nacional de Historia Natural (Chile) 319: 3-8.

Bescherelle, E. \& C.Massalongo. 1889. Hépatiques. Mission Scient. Cap Horn 1882-1883. Tome V: 201-252.

Buch, H. 1934. Verzeichnis der von H. Roivainen in Südchile während der Auer'schen Feuerlandexpedition im Jahre 1929 gesammelten PlagiochilaArten. Ann. Bryol. 7 : 1-5.

Carl, H. 1931. Die Arttypen und die systematische Gliederung der Gattung Plagiochila. Ann. Bryol. Suppl. 2:1-170.

Dugas, M. 1929.Contribution a l'etude du genre "Plagiochila" Dum. Ann. Sci. Nat. Bot. X Serie, 11: $1-199$.

Dusén, P. 1903-1906. The vegetation of western Patagonia. In: Scott W.B.(ed.). Reports of the Princeton University Expeditions to Patagonia, 1896-1899, J.B. Hatcher in charge. 8 (1): 1.33.

Engel, J. J. 1976. The southern South American Hepaticae and Anthocerotae collected by $\mathrm{H}$. Roivainen in 1969-1970, with new taxa and notes on range extensions. Ann. Bot. Fenn. 13: 132-136. 1978. A taxonomic and phytogeographic study of Brunswick Peninsula (Strait of Magellan) Hepaticae and Anthocerotae. Fieldiana Bot. 41 i viii): $1-319$.

1990. Fakkland Islands (Islas Malvinas) Hepaticae and Anthocerotophyta: a taxonomic and phytogeographic study. Fieldiana Bot. 25: 1-209.

Geissler, P. \& H. Bischler. 1989. Index Hepaticarum XI Naiadea to Pycnoscenus. Berlin-Stuttgart \& Geneve $1-353 \mathrm{pp}$, 
Hässel de Menéndez, G.G. 1983. Informaciones nomenclaturales sobre las especies del género Plagiochila (Hepaticae) de Argentina y Chile. Bol. Soc. Argent. Bot. 22(1-4): 87-129.

- 2004. Andinopatagonian species of Plagiochila (Plagiochilaceae, Marchantiophyta). I. Sectio Robustae Carl emend. Hässel and II. Sectio Equitantes Carl emend. Hässel. J. Hattori Bot. Lab. 96: $245-260$.

Hässel de Menéndez, G.G. \& S. Solari. 1985. 11.3. Catálogo de las Hepáticas. In: Boelcke O., Moore D.M. \& F.A. Roig. Transecta Botánica de la Patagonia Ausiral: $299 \cdot 342$.

Herzog, T. 1938. Contribución al conocimiento de la flora Briofita del Sur de Chile. Parte Sistemática. Arch. Esc. Farm. Fac. Cienc. Méd. Córdoba, sec. cient. $7: 1-56$.

- 1942. Die foliosen Lebermoose der Juan FernándezInseln und der Osterinsel. In C. Skotisberg (ed.): The Natural History of Juan Fernández and Eastern Island 2(5): 697-752. Uppsala.

- 1957. Eine Briophytensammlung aus dem argentinischen Nationalpark Nahuelhuapi. Darwiniana 11(2): 207-222.

- 1960. Weitere Beiträge zur Bryophytenflora Chiles. Rev. Bryol. Lichénol. 29: 183-206.

Herzog, T. \& G.H. and E. Schwabe 1940. Zur Bryophytenflora Südchiles. Beih. Bot. Centralbl. ABT B 60: 1-51.

Inoue, H. 1984. Studies on oil-bodies and chromosomes of some hepatics from southern Chile. In: Inoue H. Studies on Cryptogams in Southern Chile: 73-96.

Kühnernann, O. 1936. Contribución al catálogo briológico argentino I. Revista Centro Estud. Doat. Ci. Nat. 1(2): 85-97.
- 1949. Catálogo de las Hepáticas Argentinas. Libloa 19: 319-375.

Massalongo, C. 1906. Epatiche della Republica Argentina raccolte dal Prof. C. Spegazzini. Atti. Acad. Sci. Med. Nat. Ferrara: 1-14.

Reimers, H. 1926. Beiträge zur Bryophytenflora Sudamerikas. I u. If. Hedwisia 66: 27-78.

Schiffner, V. 1889. Lebermoose (Hepaticae), mit Zugrundelerung der von Dr. A.C.M. Gottsehe ausgeführten Vorarbeiten. In: A. Engler (ed.), Die Forschungsreise S.M.S. «Gazelle» in den Jahren 1874 bis 1877 unter Lem. Kommando des Kapitäns zur See Freiherrn von Schleinitz. 4 (Botanik) $48 \mathrm{pp}$.

Stephani, F. 1900. Beiträge zur Lebermoos-Flora Westpatagoniens und des südlichen Chile mit einer Einleitung von P. Dusén. Bih. Kongl. Svenska Vetensk.-Akad. Handl. 26, Afd. 3, 6: 1-69.

- 1901. Lebermoose der Magellansländer. Mit einer Einleitung von P. Dusén. Bih. Kongl. Svenska Vetensk.-Ahad. Handl. 26 Afd. 3, 17: 3-36.

- 1901-1905. Species Hepaticarum. Vol.Il. Georg \& Cie, Genève S.A., Genève.

- 1905. Lebermoose der Magellansländer, In: Nordenskjold, O., Wiss. Ergebnisse der Schuedischen Expedition nach den Magellanslädern 1895-1897, III Botanik: $317-350$.

- 1906-1909. Species Hepaticarum Vol. III. Georg \& Cie, Genève S.A., Genève.

- 1911. Die Lebermoose. In: Skottsberg C. Botanische Ergebnisse der Schwedischen Expedition nach Patagonien wnd dem Feuerlande 1907-1909. Kongl. Svensha Vetensk.-Akad. Handl. 46(9): 1-92.

- 1917-1925. Species Hepaticarum Vol. VI. Georg \& Cie, Genève S.A., Genève. 